metoda rozmnażania fitoplazm? / E. Gabryszewska, M. Kamińska // Rozmnażanie roślin in vitro: Materiały konferencji, Skier- nievice, 25 kwietnia 2001 r. - Skierniewice. - 2001. - P. 29-35.

3. Gall Le O. Cheravirus and Sadwavirus: Two unassigned genera of plant positivesense singlestranded RNA viruses formerly considered atypical members of the genus Nepovirus (family Comoviridae) / Gall Le O., H. Sanfacon, M. Ikegami, T. Iwanami, T. Jones, A. Karasev, K. Lehto, J. Wellink, T. Wetzel, N. Yoshikawa// Arch. Virol. - 2007. - Vol. 152. - P. 1767-1774.

4. Kulshrestha S, Hallan V, Raikhy G, Adekunle OK, Verma N,. Haq QMR \& Zaidi AA (2005) Reverse transcription polymerase chain reaction-based detection of Arabis mosaic virus and Strawberry latent ringspot virus in vector nematodes. Current Science 89, 1759-1762.

5. Lister, R.M. (1970) Nematode-borne viruses as pathogens in strawberry. In: Virus diseases of small fruits and grapevines, a handbook (Ed. by Frazier, N.W.), pp. 34-36.

6. Tzanetakis, I.E. A virus between families: Nucleotide sequence and evolution of Strawberry latent ringspot virus / I.E. Tzanetakis, J.D. Postman, R.C. Gergerich, R.R. Martin // Virus Res. - 2006. - № 121. - P. 199-204.

7. Virus taxonomy // Ninth report of the International Committee on Taxonomy of Viruses / eds. A.M. Q. King, M.J. Adams, E.B. Carstens, E.J. Lefkowitz. - Elsevier, 2012. - p. 1327.

8. Приходько, Ю.Н. Вирусные болезни плодовых и ягодных культур в европейской части России и современная схема производства и сертификации безвирусного посадочного материала / Ю.Н. Приходько // Промышленное производство оздоровленного посадочного материала плодовых, ягодных и цветочно-декоративных культур: материалы Междунар. науч.-практ. конф., Москва, 20-22 ноября 2001 г. - М., 2001. - С. 54-68.

DOI 10.18699/GPB2020-97

\title{
Особенности селекционного процесса хмеля
}

Осипова Ю.С., м.н.С., аспирант; Леонтьева В.В., н.с.; Иванова И.Ю., с.н.с. Чувашский научно-исследовательский институт сельского хозяйства лиал ФГБНУ «Федеральный аграрный научный иентр Северо-Востока имени Н.В. Рудниикого», n. Опьтный, Российская Федерация. e-mail:chniish@mail.ru

Хмель в России используется с давних времен. В диком виде он встречается повсеместно. Для создания высокопродуктивных сортов в Чувашии селекиионная работа с хмелем ведется с 1981 года. Которая состоит из нескольких питомников разных лет закладки, и изучаются в плодоносящем возрасте как минимум в течение 3-5 лет, с длительностью до 15 лет.

Ключевые слова: хмель обыкновенный, коллекция, селекция, отбор, клоны. 


\section{Features of the selection process of hops}

Yu.S. Osipova, Junior researcher, post-graduate student, V.V. Leontieva, research associate, I.Yu. Ivanova, senior researcher.

Chuvash Research Agricultural Institute - Branch of the Federal Agrarian Research Center of the North-East named N. V. Rudnitsky, Opytny settlement, Chuvash Republic, Russian Federation, e-mail: chniish@ mail.ru

Hops in Russia have been used for a long time. In the wild, it is found everywhere. To create highly productive varieties in Chuvashia, selection work with hops has been carried out since 1981. Which consists of several nurseries of different bookmark years, and are studied at the fruiting age for at least 3-5 years, with a duration of up to 15 years.

Keywords: common hops, collection, selection, selection, clones.

Создание сортов хмеля методом индивидуального клонового отбора из интродукционных популяций известно со второй половины XIX века. Основой этого метода является создание устойчивой во времени интродукционной популяции, характеризующейся высоким уровнем полиморфизма по основным хозяйственно ценным признакам. При этом возможен дальнейший отбор и закрепление их в вегетативном потомстве [1].

Селекционная работа с хмелем в Чувашии, начатая с 1981 года была направлена на усовершенствование селекционного процесса и создание новых высокопродуктивных сортов различного типа. Селекционный процесс состоял из нескольких последовательно выполняемых частей с длительным (10-12 лет) использованием насаждений во времени. Начальный этап селекции - сохранение и изучение мировой коллекции сортов хмеля, которая насчитывала более 250 сортообразцов практически из всех хмелепроизводящих стран мира [2]. По результатам изучения лучшие сорта различного происхождения вовлекались в селекционный процесс в качестве материнских форм для гибридизации или исходного материала для клоновой селекции.

Исходный материал для селекции в основном создавался методом гибридизации лучших сортов отечественной и зарубежной селекции. Гибридные питомники [3] закладываются гибридными сеянцами, полученными из гибридных семян от различных комбинаций скрещивания женских растений лучших сортов с различными мужскими формами. В первые годы в них проявляются как женские, так и мужские растения, последние подлежат выкорчевке. В гибридных питомниках образцы оцениваются по каждому растению отдельно Полученный материал фиксируется для характеристики каждого гибридного номера за годы их изучения. В гибридных питомниках изучалось в пределах 1,5-2 тыс. гибридных номеров. В селекционно-контрольных питомниках оценивалось около 100-150 селекционных номеров, являющихся клонами выделившихся гибридных номеров. В конкурсном сортоиспытании испытывались перспективные селекционные номера, выделившихся в селекционно-контрольных питомниках. 
Селекционный процесс хмеля в усовершенствованном виде в настоящее время представляет 3-х звенную схему и состоит из гибридных, селекционно-контрольных питомников и конкурсного сортоиспытания, которые в свою очередь состоят из нескольких питомников разных лет закладки и изучаются в плодоносящем возрасте как минимум в течение 3-5 лет, конкурсное сортоиспытание - за полный цикл использования по нормативным срокам - 10 лет.

Селекционно-контрольные питомники закладываются вегетативным гибридным потомством (клонами) выделенных гибридных номеров в сравнении с 2 стандартами - первый - рекомендуется сорт Подвязный (как наиболее распространенный и стабильный), а второй - последний зарегистрированный в Госреестре. В питомниках Чувашского НИИСХ разных лет закладки оценивается 100 селекционных номеров. Учеты ведутся согласно принципам ведения клонового отбора [4], селекционные работы проводятся методом индивидуального отбора. Клоны изучаются по основным хозяйственно ценным признакам, проводится оценка на отличимость, однородность и стабильность (ООС) сортовых признаков [5]. Определяется устойчивость к основным болезням и вредителям хмеля [6]. Вес сырых шишек с одного куста определяется в фазе технической спелости, содержание альфакислот в шишках - кондуктометрическим методом [7].

Конкурсное сортоиспытание завершает оценку выделенных перспективных номеров хмеля и обычно закладывается один раз в 8-10 лет. Размножение перспективных исходных растений и клонов, полученных от них, проводятся вегетативно стеблевыми черенками, заготовленными при весенней обрезке главных корневищ.

По перспективным селекционным номерам, выделившимся в конкурсном питомнике, проводится закладка питомников оригинальных насаждений в целях получения достаточного количества посадочного материала в предстоящие годы для дальнейшего расширения площадей под будущими новыми сортами. Одновременно на этих плантациях проводится производственная оценка выделенных номеров - использование обычной производственной технологии возделывания, механизированная уборка урожая и общая производственная оценка насаждений.

\section{Список литературы}

1. Леонтьева В.В. Предварительные результаты выделения клонов хмеля обыкновенного (Humulus lupulus L.) для создания новых сортов горького и ароматического типов / В.В. Леонтьева // Аграрная наука Евро-Северо-Востока, 2018. - № 1 (62). C. $42-46$.

2. Никонова 3.А. Создание и сохранение коллекции хмеля обыкновенного в качестве генофонда для селекции / 3.А. Никонова, 3.П. Короткова // Нива Поволжья. 2017. - №. 4 (45). - C. 104-108.

3. Методика Государственного сортоиспытания сельскохозяйственных культур. - Вып. 3. - М.: Колос, 1983. - С. 79-82. 
4. Белороссова, Н.В. Клоновая селекция хмеля / Н.В. Белороссова // Труды РНИХС. - Вып. 1 «Культура хмеля». - М.: Пищепромиздат, 1954. - С. 5-38.

5. Методика проведения испытаний на отличимость, однородность, стабильность. Хмель (Humulus lupulus. L.) // Официальный бюллетень Госсорткомиссии. 2008. - № 9 (139). - С. 710-720.

6. Либацкий, Е.П. Хмелеводство / Е.П. Либацкий. - М.: Колос, 1984. - 287 с.

7. Рекомендации по определению повреждений хмеля вредителями и болезнями и мероприятия по борьбе с ними. - Киев: Урожай, 1981. - С. 5-50.

DOI $10.18699 / \mathrm{GPB} 2020-98$

\section{Современные реалии производства ржи и задачи селекционной науки}

Пономарева М.Л., д.б.н., профессор, г.н.с.; Пономарев С.Н.*, д.с.-х.н., г.н.с. ТатНИИСХ ФИЦ КазНЦ РАН, г.Казань, Россия.

*e-mail: smponomarev@yandex.ru

Посевные площади ржи за последние 5 лет сократились более чем наполовину (на 1 млн га). Рассматривается значение культуры и направления интенсификации селекиии в качестве здорового и профилактического источника пищи, а также ценного компонента в рачионах сельскохозяйственных животных. Проведен анализ современного реестра селекционных достижений в сравнении с другими культурами. В связи с запросами современных перерабатывающих отраслей и стремлением к повышению качества жизни населения нужно ориентироваться на создание сортов разнопланового использования.

Ключевые слова: озимая рожь, селекиия, сорта, урожайность, адаптивность.

\section{Current realities of rye production and problems of breeding science}

Mira Leonidovna Ponomareva, D. Sc. (Biol.), chief research; Sergey Nicolaevich Ponomarev*, D. Sc. (Agr.), chief research.

Tatar Research Institute of Agriculture, FRC Kazan Scientific Center of RAS, ul. Orenburgskii trakt, 48, Kazan, 420059, Russian Federation.

*e-mail: smponomarev@yandex.ru

Rye acreage has been reduced by more than half (by 1 million ha) over the past 5 years. The importance of culture and direction of breeding intensification in the quality of healthy and preventive food source, as well as valuable component in the diets of farm animals are considered. The analysis of modern Register of selection achievements in comparison with other crops is carried out. Due to the demands of modern processing industries and the desire to improve the quality of life of the population, it is necessary to focus on creating varieties of diverse use.

Keywords: winter rye, selection, varieties, yield, adaptability. 